\title{
Penerapan Model PBL Berbantuan Role Playing untuk Meningkatan Motivasi dan Hasil Belajar IPS
}

\author{
Indra Wahyuni ${ }^{*}$, Slameto², Eunice Widyanti Setyaningtyas ${ }^{3}$ \\ 1,2,3 Jurusan Pendidikan Guru Sekolah Dasar (PGSD), FKIP Universitas Kristen Satya Wacana, Indonesia.
}

\author{
A R T I C L E I N F O \\ Article history: \\ Received 20 August 2018 \\ Received in revised form \\ 6 September 2018 \\ Accepted 19 October 2018 \\ Available online 20 \\ November 2018

\section{Kata Kunci:} \\ IPS, Problem Based \\ Learning, Role Pyaing, \\ Motivasi, Hasil Belajar. \\ Keywords: \\ Social Science, Problem \\ Based Learning, Rolle \\ Pyaing, the motivation, the \\ results of the study.
}

\begin{abstract}
A B S T R A K
Penelitian ini bertujuan untuk meningkatkan motivasi dan hasil belajar siswa kelas 5 pada mata pelajaran IPS di SD Negeri Gilirejo Kecamatan Wonosegoro, Kabupaten Boyolali dengan model PBL (Problem Based Learningl) yang berbantukan Role Playing. Penelitian ini merupakan Penelitian Tindakan Kelas (PTK) dalam 2 siklus. Instrumen yang digunakan dalam penelitian ini adalah angket untuk mengukur motivasi siswa dan soal tes untuk mengukur hasil belajar siswa. Tekhik analisis data yang digunakan dalam penelitian ini adalah tehknik deskriptif komparatif. Hasil penelitian ini menunjukkan bahwa: 1) dengan menerapkan model pembelajaran PBL berbantu Role Playing motivasi siswa meningkat; 2) demikian juga hasil belajar IPS mengalami peningkatan dari siklus I ke siklus II.
\end{abstract}

\section{A B S T R A C T}

This study aims to improve motivation and learning outcomes of grade 5 students in social studies in Gilirejo Public Elementary School, Wonosegoro, Boyolali with PBL (Problem Based Learning) model with Role Playing. This research using Classroom Action Research (CAR) in 2 cycles. The instrument used questionnaire to measure student motivation and test to measure student learning outcomes. The data analysis technique used the descriptive comparative technique. The results of this study indicate that: 1) by applying the Role Playing assisted PBL learning model, the student motivation are increases; 2) likewise social studies learning outcomes have increased from cycle I to cycle II. 


\section{Pendahuluan}

Pembelajaran IPS (Ilmu Pengetahuan Sosial) secara umum merupakan ilmu yang mempelajari tentang kehidupan bersosial, hubungan antar manusia dan dunia sekelilingnya. Mata pelajaran IPS mengkaji tentangbhubungan antar manusia dan yang menjadi telaahnya adalah kehidupan nyata manusia. Luasnya kajian IPS ini mencangkup berbagai kehidupan yang beraspek majemuk baik hubungan sosial, ekonomi, psikologi, budaya, sejarah maupun politik, semuanya dipelajari dalam ilmu sosial. Dengan demikian siswa dan siswa yang mempelajari IPS dapat menghayati dan mempelajari masa sekarang dengan dibekali pengetahuan tentang masa lampau umat manusia. Pengertian umum ini tidak jauh berbeda dari pandangan Suwarso, Widiarto (2010) mengemukakan bahwa IPS adalah kajian tentang manusia dan dunia sekelilingnya. IPS mengkaji tentang hubungan antar manusia dan yang menjadi telaahnya adalah kehidupan nyata manusia. Luasnya kajian IPS ini mencangkup berbagai kehidupan yang beraspek majemuk baik hubungan sosial, ekonomi, psikologi, budaya, sejarah maupun politik, semuanya dipelajari dalam ilmu sosial. Dengan demikian siswa yang mempelajari IPS dapat menghayati dan mempelajari masa sekarang dengan dibekali pengetahuan tentang masa lampau umat manusia. Menurut Hakim (2014) pembelajaran IPS mengajarkan tentang bagaimana manusia berinteraksi antar sesama maupun dengan lingkungannya.

Berkaitan dengan tujuanya, Susanto (2013) mengemukakan tujuan pembelajaran IPS adalah dengan mempelajari kondisi masyarakat seperti yang dimuat dalam pendidikan IPS, maka siswa akan dapat mengamati norma-norma atau peraturan serta kebiasaan-kebiasaan baik yang berlaku dalam masyarakat tersebut, sehingga siswa mendapat pengalaman langsung adanya hubungan timbal balik yang saling mempengaruhi antara kehidupan pribadi dan masyarakat.

Pembelajaran IPS SD merupakan konsep yang berkaitan dengan kehidupan masyarakat dan lingkungan. Mata pelajaran ini mengandung makna komunikasi, bekerjasama, dan berkompetisi dalam masyarakat. Dalam dunia pendidikan saat ini antara guru dan murid tidak terlepas dari masalah-masalah yang berkaitan didalam pembelajaran. Salah satu contohnya cara mengajar guru yang masih bersifat konvensional merupakan salah satu faktor dalam masalah pembelajaran yang ada di sekolah dasar terutama dalam mata pelajaran ilmu didominasi oleh kegiatan membaca dan menghafal.

Kegiatan belajar membaca dan menghafal bagi anak merupakan kegiatan yang membosankan dan sulit, hal ini mempengaruhi motivasi dan hasil belajar anak dalam mata pelajaran pelajaran Ilmu Pengetahuan Sosial. Sudah saatnya guru IPS membuka paradigma baru dalam pola pengajaran di kelas di mana pelajaran IPS yang selama ini di anggap sebagai mata pelajaran hafalan yang membosankan dan bahan pelajaranya yang terlalu banyak, beribah menjadi sesuatu yang menyenangkan. Sehingga menumbuhkan motivasi belajar dan dapat meningkatkan hasil belajar yang rendah.

Hakikat belajar itu sendiri ada beberapa pandangan ahli, Sudjana (2009) misalnya berpendapat belajar adalah suatu proses yang ditandai dengan adanya perubahan pada diri seseorang. Perubahan sebagai hasil dari proses belajar dapat ditunjukkan dalam berbagai bentuk seperti perubahan pengetahuan, sikap dan tingkah laku, keterampilan, kecakapan, kebiasaan serta perubahan pengetahuan, sikap dan tingkah laku, keterampilan, kecakapan, kebiasaan serta perubahan aspek-aspek lain yang ada pada individu yang belajar.

Sedangkan Yustina (2014) mengemukakan masalah belajar adalah masalah bagi setiap manusia, dengan belajar manusia memproleh keterampilan, kemampuan sehingga terbentukalah sikap dan bertambah ilmu pengetahuan. Jadi hasil belajar itu adalah suatu hasil nyata yang dicapai oleh siswa dalam usaha menguasai kecakapan jasmani dan rohani si sekolah yang diwujudkan dalam bentuk raport pada setiap semester. Dari dua pandangan nampak bahwa dampak dari proses belajar yang berhasil akan menumbuhkan motivasi siswa.

Hamzah (2015) mengemukakan hakikat motivasi belajar adalah dorongan internal dan eksternal pada siswa-siswa yang sedang belajar untuk mengadakan perubahan tingkah laku, pada umumnya dengan beberapa indikator atau unsur yang mendukung. Dalam kegiatan belajar mengajar disekolah merupakan hal yang penting setidaknya para siswa memiliki motivasi untuk belajar karena kegiatan akan berhasil baik apabila anak yang bersangkutan mempunyai motivasi yang kuat. Menurut Malthis (2006:114), motivasi adalah keinginan dalam diri seseorang yang menyebabkan orang tersebut bertindak.

Pada aktifitas belajar mengajar, setiap siswa membutuhkan suatu motivasi atau dorongan agar beberapa keinginannya dapat terpenuhi. Hamzah (2015) membagi motivasi menjadi dua jenis yaitu motivasi intrinsik dan motivasi ekstrinsik. Motivasi intrinsik yaitu motif terjadi secara aktif dan tidak memerlukan rangsangan dari luar karena pada setiap diri individu sudah memiliki sebuah dorongan untuk menjalankan sesuatu. Motivasi ekstrinsik yaitu motif-motif aktif yang memiliki fungsi masingmasing karena mendapatkan rangsangan dari luar. 
Zainal (2016) mengemukakan bahwa tujuan pendidikan bisa diklasifikasikan menjadi tiga kategori, yaitu keterampilan berpikir, tingkah laku (perilaku), dan keterampilan fisik yang mewakili tiga ranah (domain) pendidikan yaitu ranah kognitif (cognitive), afektif (affective), dan psikomotorik (psychomotor). Untuk itu penilaian hasil belajar seharusnya mencakup tiga ranah pendidikan tersebut. Berdasarkan permasalahan yang ada dalam rangka untuk meningkatkan hasil belajar siswa mata pelajaran IPS kelas V SD Negeri Gilirejo, maka diperlukan upaya untuk memilih dan menggunakan model pembelajaran yang sesuai dengan karakteristik siswa.

Peneliti menerapkan metode PBL (Problem Based Learning) sebagai langkah awal dalam mealukan penelitian sebelum menerapkan Model Pembelajaran Role Playing yang nantinya akan dijadikan tolak ukur berhasil dan tidaknya penelitian berlangsung. Penerapan pendekatan PBL menunjukkan arah perbaikan peningkatan prestasi belajar mahasiswa. Hal ini, menunjukan pula terdapat peningkatan kualitas perkuliahan Manajemen Kurikulum. PBL (Problem Based Learning) permasalahan sebagai langkah awal untuk meningkatkan hasil belajar siswa yang berbantukan dengan menerapkan pembelajaran Role Playing (bermain peran). Menurut Eggen dkk (2013: 307) Problem Based Learning dilaksanakan dalam kelompok yang cukup kecil, sehingga semua siswa terlibat dalam proses itu. Dengan membuat siswa terlibat dalam pembelajaran mereka sendiri, keuntungan yang mereka dapat lebih luas cakupanya dan mereka bisa menyalurkan serta menambah kemampuanya seperti kemampuan berkomunikasi, kerja tim serta memecahkan. Orhan \& Ruhan (2007), menyatakan bahwa model PBL memberikan dampak positif pada prestasi akademik siswa dan sikap siswa. Selanjutnya menurut Ibrahim dan Nur (Rusman 2012:241) pembelajaran berbasis masalah merupakan salah satu pendekatan pembelajaran yang digunakan untuk merangsang berpikir tingkat tinggi siswa dalam situasi yang berorientasi pada masalah dunia nyata, termasuk di dalam belajar mengajar. Sedangkan Menurut.

Tujuan PBL menurut Arends (2008:70) antara lain adalah, membantu siswa mengembangkan keterampilan berfikir dan ketrampilan pemecahan masalah, belajar peranan orang dewasa secara autentik, Siswa memuliki rasa percaya diri atas kemampuan yang dimilikinya sendiri, menumbuhkan rasa inisiatif siswa motivasi internal untuk belajar dan dapat mengembangkan hubungan interpersonal dalam kelompok. Penelitian oleh Wau (2017) menunjukkan bahwa model Problem Based Learning berpengaruh terhadap hasil belajar IPS.

Mawardi (2017: 29) mengatakan media adalah pembelajaran segala sesuatu yang dapat digunakan sebagai sarana informasi materi pembelajaran sedangkan, menurut Dina Indriana (2011:27) dasar terpenuhinya kebutuhan dan tercapainya tujuan pembelajaran. Menurut Atmaja (2016), pengertian peran dapat didefinisikan sebagai suatu rangkaian perasaan, ucapan dan tindakan, sebagai suatu pola hubungan unik yang ditunjukkan oleh individu terhadap individu lain. Sedangkan menurut Aziz (2008), bermain peran adalah berakting sesuai dengan peran yang telah ditentukan terlebih dahulu untuk tujuan-tujuan tertentu seperti menghidupkan kembali suasana historis misalnya mengungkapkan kembali perjuangan para pahlawan kemerdekaan atau mengungkapkan kemungkinan keadaan yang akan datang. Djamarah dan Zain (2006: 88) Role Playing dan sosiodrama dapat dikatakan sama artinya, model Role Playing pada dasarnya mendramatisasikan tingkah laku dalam hubungannya dengan masalah sosial, sedangkan sosiodrama merupakan metode mengajar yang pelaksanaannya peserta didik mendapat tugas untuk mendramatisasikan situasi social, sehingga dalam pemakainya sering disilih gantikan.

Menurut Huda (2015), Role Playing atau bermain peran adalah model pembelajaran sebagai bagian dari simulasi yang diarahkan untuk mengkreasi peristiwa sejarah, mengkreasi peristiwa-peristiwa aktual, atau kejadian-kejadian yang mungkin muncul pada masa mendatang. Berdasarkan pendapatpendapat di atas, dapat disimpulkan bahwa model pembelajaran bermain peran (Role Playing) adalah cara yang digunakan guru dalam proses pembelajaran dengan memberikan suatu topik/masalah yang dipecahkan oleh peserta didik dengan memainkan peran dalam hal ini terkait dengan pembelajaran.

Tujuan yang diharapkan dengan penggunaan metode bermain peran (Role Playing) menurut Huda (2015) antara lain adalah agar siswa dapat menghayati dan menghargai perasaan orang lain, dapat belajar bagaimana membagi tanggung jawab, dapat belajar bagaimana mengambil keputusan dalam situasi kelompok secara spontan dan merangsang kelas untuk berpikir dan memecahkan masalah. Terdapat sintak dalam menerapkan model pembelajaran Role Playing seperti dalam lampiran.

Berdasarkan observasi terdapat proses pembelajaran IPS di kelas V SD Negeri Gilirejo diperoleh beberapa faktor yang menyebabkan rendahnya motivasi belajar dan hasil belajar siswa. Guru hanya sebatas menerangkan materi yang ada dalam buku paket siswa dan contoh-contoh lain yang belum terdapat dalam buku paket siswa,pembelajaran yang bersifat monoton membuat siswa kurang bersemangat saat pembelajaran berlangsung, jadi guru membutuhkan model pembelajaran yang baru untuk meningkatkan hasil belajar sebelumnya 36\% yang mencapai ketuntasan,rendahnya partisipasi siswa dalam mengikuti proses pembelajaran yang menurut siswa terlalu banyak kegiatan menghapal, kurangnya model pembelajaran yang inofatif, kemudian meminta siswa untuk mengerjakan soal latihan 
yang ada sebagai evaluasi pembelajaran. Selain itu, pembelajaran yang terjadi belum memfasilitasi kegiatan pembelajaran peserta didik yang sebagian besar cenderung siswa aktif. Sehingga banyak siswa yang sibuk dengan kegiatanya sendiri seperti : berbicara dengan teman seblah, memukul meja, menghadap ke belakang, dan bahkan siswa tidur. Atau dapat dikatakan pelaksanaan pembelajaran yang terjadi dapat dikatakn belum meperhatikan karakteristik mata pelajaran IPS dan karakteristik siswa.

Kondisi rendahnya motivasi belajar siswa dan hasil belajar siswa pada mata pelajaran IPS hasil belajar siswa pada mata pelajaran IPS kelas V SD Negeri Gilirejo sebelum pelaksanaan tindakan diperoleh dari data tes kondisi awal siswa sebelum siklus I. Dibuktikan dengan motivasi belajar mencapai sebesar 55\% dalam kategori "cukup" sedangkan untuk hasil belajar nilai ketuntasan hanya sebesar 35\% (7 siswa) yang memiliki nilai tuntas. Hal ini sangat jauh dari indikator kinerja yang diharpkan yaitu motivasi mencapai 70\% dalam kategori "sangat baik" dan hasil belajar mencapai nilai ketuntasan sebasar $80 \%$ dilihat dari nilai siswa dan perubahan itu menjadika hasil belajar yang menigkat.

Berdasarkan permasalahan yang ada dalam rangka untuk meningkatkan motivasi dan hasil belajar siswa mata pelajaran IPS kelas V SD Negeri Gilirejo, dapat menggunakan model pembelajaran Role Playing. Bedasarkan permasalahan tersebut maka tujuan penelitian ini adalah untuk meningkatkan motivasi dan hasil belajar siswa mata pelajaran IPS melalui penerapan model pembelajaran Role Playing pada siswa kelas V SD Negeri Gilirejo semester II Tahun Pelajaran 2017/2018.

\section{Metode}

Penelitian ini merupakan Penelitian Tindakan Kelas (PTK) dalam 2 siklus. Subjek penelitian ini adalah siswa kelas V SDN Gilirejo sejumlah 20 siswa. Penelitian ini dilaksanakan pada semster II tahun 2017/2018. Prosedur yang diterapkan peneliti adalah PTK yang terdiri dari 4 tahap (a) perencanaan. (b) pelaksanaan tindakan (c)observasi, (d) refleksi. Instrumen yang digunakan dalam penelitian ini adalah angket untuk mengukur motivasi siswa dan soal tes untuk mengukur hasil belajar siswa. Tekhik analisis data yang digunakan dalam penelitian ini adalah teknik deskriptif komparatif. Indikator keberhasilan dalam penelitian ini jika tingkat motivasi pembelajaran mencapai 70\% dalam kategori "sangat baik" dan hasil belajar mencapai $80 \%$ dengan $\mathrm{KKM} \geq 65$.

\section{Hasil dan Pembahasan}

Pada siklus I dilaksanakan tiga kali pertemuan dalam penerapan model pembelajaran PBL berbantu Role Playing pada materi kompetensi dasar 2.2 "Menghargai jasa dan peran tokoh perjuangan dalam mempersiapkan kemerdekaan Indonesia".

Pada pembelajaran siklus I dilakukan pengukuran terhadap motivasi siswa dan diperoleh data siswa yang mencapai kategori "baik" 16 siswa dan yang mencapai motivasi "sangat baik" mencapai 4 siswa dengan persentase $80 \%$ dan sangat baik $20 \%$. Selanjutnya pengukuran hasil belajar yang dilakukan diperoleh data rata-rata kelas mencapai 74,1.

Pada Siklus II ini juga dilaksanakan tiga kali pertemuan dengan menerapkan model pembelajaran Role Playing pada materi komptensi dasar 2.3 Menghargai jasa dan peranan tokoh dalam memproklamasikan kemerdekaan Indonesia. Diperoleh data siswa yang mencapai motivasi dalam kategori "baik" 5 siswa dan yang mencapai motivasi "sangat baik" mencapai 15 siswa dengan persentase 25\% dan 75\%. Dari pengukuran hasil belajar siklus II diperoleh data siswa yang mencapai ketuntasan hasil belajar dengan KKM 65 mencapai 16 siswa dengan persentase $80 \%$ dan 4 siswa yang tidak tuntas dengan persentase $20 \%$ dengan rata-rata kelas 75,3.

Perbandingan motivasi belajar siswa dari sebelum tindakan (pra siklus), siklus I, dan siklus II setelah dilakukan pengamatan saat proses pembelajaran diperoleh data sebagai berikut:

Tabel 1. Perbandingan Motivasi Bealajar siswa Pra Siklus, Siklus I dan Siklus II

\begin{tabular}{|c|c|c|c|c|}
\hline No. & Motivasi Belajar Siswa & Pra Siklus & Siklus I & Siklus II \\
\hline 1. & Sangat Baik & - & 4 siswa $(20 \%)$ & 15 siswa $(75 \%)$ \\
\hline 2. & Baik & 9 siswa $(45 \%)$ & 16 siswa $(80 \%)$ & 5 orang $(25 \%)$ \\
\hline 3. & Cukup & 11 siswa (55\%) & - & - \\
\hline 4. & Kurang & - & - & - \\
\hline 5. & Sangat Kurang & - & - & - \\
\hline
\end{tabular}


Dari tabel di atas dapat dilihat bahwa terjadi kenaikan motivasi belajar siswa yang ditunjukkan dengan adanya kenaikan pada presentase kelas dari pra siklus, siklus I dan siklus II. Terjadi kenaikan yang siginifikan dari ketiga tahap tersebut pada mata pelajaran IPS untuk dua Kompetensi Dasar yang diguanakan dalam siklus I dan siklus II.

Perbandingan hasil belajar aspek kognitif siswa dari sebelum tindakan (pra siklus), siklus I, dan siklus II setelah dilakukan pengamatan saat proses pembelajaran diperoleh data sebagai berikut:

Tabel 2. Perbandingan Hasil Belajar Siswa Aspek Kognitif Pra Siklus, Siklus I dan Siklus II

\begin{tabular}{|c|c|c|c|c|}
\hline No. & Hasil Belajar Siswa & Pra Siklus & Siklus I & Siklus II \\
\hline 1. & Nilai Tertinggi & 70 & 83 & 92 \\
\hline 2. & Nilai Terendah & 27 & 42 & 58 \\
\hline 3. & Nilai Rata-rata & 53,4 & 66,3 & 77,6 \\
\hline 4. & Ketuntasan Belajar & $35 \%$ & $50 \%$ & $80 \%$ \\
\hline
\end{tabular}

Pada tabel di atas terlihat adanya kenaikan dari prasiklus dengan nilai ketuntasan 35\% kemudian naik disiklus I menjadi 50\% dan disiklus II mejadi 80\%. Dengan demikian model pembelajaran Role Playing dapat meningkat hasil belajar aspek kognitif pada mata pelajaran IPS.

Perbandingan hasil belajar aspek psikomotorik siswa dari siklus I dan siklus II setelah dilakukan pengamatan saat proses pembelajaran diperoleh data sebagai berikut :

Tabel 3. Perbandingan Hasil Belajar Siswa Aspek Psikomotorik Pra Siklus, Siklus I dan Siklus II

\begin{tabular}{|c|c|c|c|}
\hline No. & Hasil Belajar Siswa & Siklus I & Siklus II \\
\hline 1. & Nilai Tertinggi & 92 & 92 \\
\hline 2. & Nilai Terendah & 50 & 58 \\
\hline 3. & Nilai Rata-rata & 67,5 & 77,2 \\
\hline
\end{tabular}

Pada tabel di atas terlihat adanya kenaikan dari siklus I dengan nilai rata-rata 67,5 dan kemudian naik disiklus II menjadi 77,2. Dengan demikian model pembelajaran Role Playing dapat meningkat hasil belajar aspek psikomotor pada mata pelajaran IPS.

Perbandingan hasil belajar aspek afektif siswa dari siklus I dan siklus II setelah dilakukan pengamatan saat proses pembelajaran diperoleh data sebagai berikut :

Tabel 4. Perbandingan Hasil Belajar Siswa Aspek Afektif Pra Siklus, Siklus I dan II

\begin{tabular}{|c|c|c|c|}
\hline No. & Hasil Belajar Siswa & Siklus I & Siklus II \\
\hline 1. & Nilai Tertinggi & 83 & 83 \\
\hline 2. & Nilai Terendah & 33 & 47 \\
\hline 3. & Nilai Rata-rata & 74,1 & $75,3$. \\
\hline
\end{tabular}

Pada tabel di atas terlihat adanya kenaikan dari siklus I dengan nilai rata-rata 61,4 dan kemudian naik disiklus menjadi 67,6. Dengan demikian model pembelajaran Role Playing dapat meningkat hasil belajar aspek afektif pada mata pelajaran IPS.

Peneliti dengan menerapkan model pembalajaran Role Playing dari hasil yang di dapatkan terbukti dapat meningkatkan motivasi belajar dan hasil belajar IPS siswa kelas V SD Negeri Gilirejo Kecamatan Wonosegoro Semester II Tahun Ajaran 2017/2018. Hal ini dapat dilihat pada siklus I dengan menerapkan model pembelajaran Role Playing pada materi kompetensi dasar 2.2 Menghargai jasa dan peranan tokoh perjuangan dalam mempersiapakan kemerdekaan Indonesia. Diperoleh siswa yang mencapai motivasi dalam kategori "baik" mencapai 16 siswa dan yang mencapai 4 siswa dengan presentase sangat baik $20 \%$ dengan rata-rata kelas 75.3. siswa yang mencapai ketuntasan hasil belajar dengan presentase KKM 65 mencapai 10 siswa dengan presentase 50\% dan 10 siswa yang tidak tuntas dengan presentase $50 \%$ dengan rata-rata $65,1$.

Siklus II dengan menerapkan model pembelajaran Role Playing pada materi kompetensi dasar 2.3 Mengahargai jasa dan peranan tokoh dalam memproklamasikan kemerdekaan Indonesia. Diperoleh data siswa yang mencapai motivasi "sangat baik" mencapai 15 siswa dengan presentase baik 25\% sangat baik $75 \%$ dengan rata-rata kelas 84,4. Siswa yang mencapai ketuntasan hasil belajar dengan KKM 65 mencapai 
16 siswa dengan presentase $80 \%$ dan 4 siswa yang tidak tuntas dengan presentase $20 \%$ dengan rata-rata kelas $74,1$.

Hasil penelitian ini sejalan dengan pendapat Majid (2014:163), bahwa role play atau bermain peran adalah model pembelajaran sebagai bagian dari simulasi yang diarahkan untuk mengkreasi peritiwa sejarah, aktual, atau kejadian-kejadian yang mungkin muncul dimasa mendatang. Model bermain peran (Role Playing) mempunyai beberapa kelebihan menurut Huda (2015) antara lain adalah 1) dapat memberikan kesan pembelajaran yang kuat dan tahan lama dalam ingatan siswa, 2) bisa menjadi pengalaman belajar menyenangkan yang sulit untuk dilupakan 3) membuat suasana kelas menjadi leih dinamis dan antusias 4) membangkitkan gairah dan semangat optimisme dalam diri siswa serta menumbuhkan rasa kebersamaan dan 5) memungkinkan siswa untuk terjun langsung memerankan sesuatu yang akan dibahas dalam proses belajar.

Model PBL pada peneliti ini mempunyai beberapa kelebihan dimana pandangan atau point view tentang apa dan bagaimana peserta didik belajar, disamping mengembangkan keterampilan memecahkan masalah, pemeblaajran PBL juga mendorong siswa untuk berkolaborasi dimana kegiatan dalam kegiatan berlangsung siswa dibagi menjadi beberapa kelompok. Dengan demikian pembelajaran berbasis masalah merupakan model pembelajaran yang berangkat dari pemahaman siswa tentang suatu masalah, menemukan alternatif solusi atas masalah kemudian memilih solusi yang tepat untuk digunakan dalam memecahkan masalah tersebut (Sutirman, 2013:39).

Temuan penelitian ini juga sejalan dengan penelitian Mustofa Kamil, Sriyanti, dan Bambang Mardisentosa (2018: 32) yang menyatakan bahwa Penerapan pendekatan PBL menunjukkan arah perbaikan peningkatan prestasi belajar. Demekian juga hasil penelitian dari Orhan \& Ruhan (2007), menyatakan bahwa model PBL memberikan dampak positif pada prestasi akademik siswa. Penelitian Melissa (2016) tentang peningkatan kemandirian dan prestasi belajar matematika dengan pendekatan PBL di SMP. Penelitian dilakukan terhadap 34 siswa kelas VII di SMP Negeri 15 Yogyakarta. Penelitian menyimpulkan bahwa pendekatan PBL dapat meningkatkan kemandirian dan prestasi belajar matematika siswa. Penelitian Hartati \& Sholihin (2015) menunjukkan bahwa penerapan model PBL pada pembelajaran IPA memiliki dampak yang positif terhadap peningkatan kemampuan berpikir kritis siswa.

Model pembelajaran Role Playing pada penelitian ini mempunyai beberapa kelebihan dibandingkan dengan beberapa penelitian relevan yang pernah dilakukan yaitu penataan tempat yang bervariatif dalam setiap pertemuan dalam siklus diatur sedemikian rupa sehingga membuat suasana berbeda dalam kelas dan memberikan kesan pembelajaran yang semangat dalam setiap pertemuannya dan siswa yang terlibat dalam proses pembelajaran dapat bebas berekspresi dalam pemerananya dan membuat atribut dalam setiap penampilan untuk mendukung kegiatan proses pembelajaran.

Menurut Mulyasa (2013 : 163) Role Playing atau bermain peran adalah model pembelajaran sebagai bagian dari siulasi yang diarahkan untuk mengkreasi peristiwa sejarah, mengkreasi peristiwaperistiwa aktual, atau kejadian-kejadian yang mungkin pada masa mendatang.

\section{Simpulan dan Saran}

Dari hasil penelitian dan pembahasan dapat disimpulkan bahwa: 1) dengan menerapkan model pembelajaran PBL berbantu Role Playing motivasi siswa meningkat, simpulan ini diperoleh dari temuan hasil pengukuran motivasi belajar siswa siklus I mencapai rata-rata $45 \%$ dan siklus ke II mencapai $80 \%$; 2) demikian juga hasil belajar IPS mengalami peningkatan dari siklus I ke siklus II dengan rerata skor hasil belajar siklus I 74,1 dan siklus II mencapai 75,3.

Berdasarkan simpulan penelitian yang telah dipaparkan, maka dapat diajukan beberapa saran guna peningkatkan kualitas pembelajaran IPS sebagai berikut. Pertama, model PBL hendaknya diperkenalkan dan dikembangkan kepada pendidik guna menciptakan suasana yang menyenangkan namun tetap fokus. Kedua, bagi lembaga pendidikan yang mengembangkan misi mendidik calon-calon guru, khususnya calon guru sekolah dasar, hendaknya terus menerus memperkenalkan dan melatih para calon guru untuk menerapkan model-model pembelajaran kooperatif yang diberi inovasi-inovasi yang sesuai dengan karakteristik siswa di sekolah dasar. Sehingga pembelajaran yang diterapkan pada saat sudah menjadi guru nanti, lebih bermakna dan menyenangkan bagi peserta didik. Ketiga, Untuk penyempurnaan penelitian ini, disarankan kepada peneliti lain untuk mengadakan penelitian lanjut dengan melibatkan variabel-variabel lain, misalnya keterampilan hidup, kecerdasan interpersonal dan lain sebagainya. 


\section{Daftar Rujukan}

Akinoglu, O., \& Tandogan, R. O. 2007. The effects of problem-based active learning in science education on student's aca $\neg$ demic achievement, attitude and concept learning. Eurasia Journal of Mathemat?ics, Science \& Technology Education, 3 (1), 71-81,

Anggraini, Shinta, Syaiful M, dan. M. Basri. 2016. Pengaruh Model Problem Based Learning (PBL) Terhadap Hasil Belajar Sejarah Siswa. PESAGI (Jurnal Pendidikan dan Penelitian Sejarah) Volume 4 Nomor 1.

Arikunto, Suharsimi. 2010. Penelitian Tindakan Kelas untuk Guru, Kepala Sekolah dan Pengawas. Yogyakarta. Aditya Media,

Atmaja, N, P. 2016. Evaluasi Belajar Mengajar. Yogyakarta. Diva Press,

Aziz, A. 2008. Metode dan Model-Model Mengajar IPS. Bandung,

Alfabetauda, Miftahul. Model-Model Pengajaran dan Pembelajaran. Yogyakarta. Pustaka Pelajar, 2015.

Djamarah, Bahri dan Aswan Zain. 2006. Strategi Belajar Mengajar. Jakarta : PT. Rineka Cipta

Hakim, Arif Rahman, Wayan Lasmawan, Nyoman Dantes. 2014. Pengaruh Metode Bermain Peran Terhadap Kemampuan Komunikasi Dan Hasil Belajar Ips Kelas V Sdn Segugus Karang Baru. eJournal Program Pascasarjana Universitas Pendidikan Ganesha Program Studi Pendidikan Dasar Volume 4 .

Hartati, R. \& Sholihin, H. 2015. Meningkatkan Kemampuan Berpikir Kritis Siswa Melalui Implementasi Model Problem Based Learning (PBL) Pada Pembelajaran IPA Terpadu Siswa SMP. Makalah disajikan dalam Prosiding Simposium Nasional Inovasi dan Pembelajaran Sains 2015 (SNIPS), 8-9 Juni 2015

Malthis. 2006. Manajemen Sumber Daya Manusia. Salemba Empat. Jakarta,

Mawardi. 2017.Merancang Model Dan Media Pembelajaran. Scholaria: Jurnal Pendidikan dan Kebudayaan. $8(1), 26-40$,

Melissa, M.M. 2016. Peningkatan Kemandirian Dan Prestasi Belajar Matematika Dengan Pendekatan Problem-Based Learning (PBL) di kelas VII ESMP Negeri 15 Yogyakarta. Jurnal Ilmiah Edukasi Matematika (JIEM), 2(1):1-18

Mustofa. 2018. Penerapan Metode Pembelajaran Berbasis Masalah. Pelita Jurnal Peneloitian dan Karya Imiah. , Vol 13, No 1, 32-45: Januari-April,

Rusman. 2012. Model-Model Pembelajaran. Jakarta :Raja grafindo Persada,

Savin-Baden, M. Major, C.H.. 2004. Foundations of Problem Based Learning New York:open University Press.McGRAW - Hill Education,

Sudjana, Nana. 2009.Dasar-dasar Prosedur Belajar Mengajar. Bandung. Sinar Baru Algesindo,

Susanto, Ahmad. 2013. Teori Belajar dan Pembelajaran. Jakarta. Kencana Prenada Media Group,

Sutirman. 2013. Media Dan Model Model Pembelajaran Inovatif. Yogyakarta: Graha Ilmu

Suwarso, Widiarto, T. 2010. Pendidikan Ilmu Pengetahuan Sosial (Pembelajaran IPS). Salatiga: Widya Sari Press,

Tina Sri Sumartini, 2015. Peningkatan Kemampuan Penalaran Berbasis Masalah. Jurnal Pendidikan Matematika. Volume 5, Nomor 1, April 
Uno, B., Hamzah. 2015. Teori Motivasi dan Pengukurannya (Analisis di Bidang Pendidikan). Jakarta: Bumi Aksara,

Wardana, I Komang Ngurah, I Ketut Adnyana Putra, I.G.A.A Sri Asri. 2014. Pengaruh Model Pebelajaran Role Playing Terhadap Keterampilan Berbicara Bahasa Indonesia Siswa Kelas V Sd Gugus Ii Kecamatan Karangasem. e-Journal Mimbar PGSD Universitas Pendidikan Ganesha Jurusan PGSD Vol: 2 No: 1.

Wau, Maria Patrisia. 2017. Pengaruh Model Problem Based Learning Terhadap Hasil Belajar IPS Pada Siswa Kelas Iv Sdi Bajawa Kecamatan Bajawa Kabupaten Ngada . Journal of Education Technology. Vol. 1 No. (4) pp. 239-245

Widya Irayani, Kusmanto, Upaya Meningkatkan Motivasi dan Prestasi Belajar Matematika, Menggunakan Model Kooperatif Tip Group Investigation Kelas IV SD Negeri Sokorini 1 Muntilan Tahun Ajaran 2015/2016. Trihayu UST, Vol.3, No. 3, Januari 2017

Yustiana, dkk. 2014. Penilaian Belajar Siswa di Sekolah. Sleman. PT Kanisius,

Zainal, A. 2016. Evaluasi Pembelajaran. Bandung. PT Remaja Rosdakarya, 